\title{
Nutritional Value and Consumer Acceptability of Fresh, Sundried and Smoke-Dried Tilapia in Zambia
}

\author{
Henry Kabango Kanyembo, Confred G. Musuka \\ The Copperbelt University, School of Natural Resources, Kapasa Makasa University Campus, Chinsali, Zambia \\ *Corresponding Author: Confred G. Musuka, The Copper belt University, School of Natural \\ Resources, Kapasa Makasa University Campus, Chinsali, Zambia
}

\begin{abstract}
A study on nutritional value and consumer acceptability of sundried, smoke dried and fresh tilapia species was undertaken in the Copperbelt Province of Zambia. The study involved undertaking a survey at three major markets, namely; Chisokone (in Kitwe), Roan (in Luanshya), and Main Masala (in Ndola) to ascertain; prevailing prices of fish, consumer preferences and acceptability. In addition, proximate chemical analysis was conducted on sundried, smoke dried and fresh tilapia species in the Environmental Engineering Laboratory of the Copper belt University, in order to determine some nutrient composition. Results of the survey indicated that fresh fish was by far the cheapest (53\%) and most preferable by consumers (68\%) compared to sundried and smoke dried. At the same time, smoke dried fish was perceived to be the most expensive on the market. Similarly, proximate chemical analysis results indicated that smoke dried fish had the highest crude protein content (69.4\%), while fresh fish had the least (57.4\%) content. Meanwhile, fresh fish showed that it had the highest level of ash (17.6\%), while sundried had the least (5.5\%). However, ether extract was much higher in smoke dried fish (24.6\%) compared with the other two types. The highest amount of moisture content was recorded in fresh fish (67.9\%) and the least was recorded in smoke dried (7.37\%) fish. Based on this study, it was established that there were several factors underlying the acceptance of sundried, smoke dried and fresh tilapia fish species on the market. Some of the factors included: health reasons, preference, taste, diversity of preparation methods and family satisfaction, quality of the fish being sold and place where trading was taking place. The consumers on the other hand based their acceptance to purchase the commodity on factors to do with their individual satisfaction of some of the aforementioned prevailing conditions. Nutritional value and consumer acceptance of tilapia species was largely dependent on processing method used, that were seen to affect both the nutrient composition as well as the consumer preference in buying the commodity. Furthermore, many consumers attributed their inability to purchase much more of sundried and smoke dried fish to higher prices being charged by traders.
\end{abstract}

Keywords: Tilapia, Fresh, Sundried, Smoke-dried, Nutritional Value, Consumer acceptability.

\section{INTRODUCTION}

Fish represents a valuable source of protein and nutrients in the diet of many people and its importance in contributing to food security is rising significantly. The total food supply available from fisheries in the live weight terms is estimated to be slightly higher than $16 \mathrm{Kg} / \mathrm{year}$ for each of the world inhabitants (Adam and Sidahmed, 2012). In Africa, it is the most readily available source of protein which is easily accessible by most native individuals (Ande et al., 2012). In West Africa, fish provides about $30 \%-80 \%$ of the total animal protein intake of the coastal people and the amino composition of fish is compared favorably well with egg, milk and meat (Adenike, 2014).

In Zambia, 106,798 tons of fish is produced annually (about 86,527 tons from capture fisheries and 20,271 tons from aquaculture), with the gross value add of USD147 million (SADC, 2016). Most of this fisheries in Zambia are located in places very far from urban areas where most of the fish marketing takes place such as the Copperbelt and Lusaka Provinces (Musumali et al., 2009). The fisheries sector however, because of its mostly rural setting, continued to contribute significantly to rural development in terms of employment and income generation and reducing poverty (ZDA, 2011). The fisheries sector employs about 325,000 people $(313,000$ in capture fisheries and 12,000 in aquaculture) (SADC, 2016), deriving their livelihood directly as fishers and fish farmers, or indirectly as traders, processors and other service providers and it played a vital role. According to Musumali et 
al., (2009), demand for fish is growing strongly in Zambia as elsewhere in response to population growth and increasing urbanization.

In addition to capture fisheries, Zambia's aquaculture fish production has grown significantly in the last two decades. From a total production of only 5,000 tons of fish per annum in 2006, the country in 2013 produced about 20,000 tons (Kefi and Mukuka, 2015). Fish demand was an attractant to investment in aquaculture (Kefi and Mukuka, 2015). The increase in aquaculture production was mainly due to the rapid adoption of cage fish farming which is a high intensive system. Furthermore, the emerging of the private sector in fish seed and feed production had been too a catalyst in the upscaling of fish production in Zambia (Kefi and Mukuka, 2015).

Although fish is an important component in the diets of many communities in Zambian, the availability of its vital nutrients has been shown to largely depend on the methods of storage (Mphande and Chama, 2015). Musumali et al., (2009) further reported that most fish landed in Zambia was generally caught overnight by artisanal fishing through gill netting and seine netting. The setting of gillnets was done before dusk and hauled in during the early morning hours. The nets usually spent 11 to 14 hours in water before they were hauled. The fish from those fishery areas were preserved by various processes before it reaches the markets in order to prolong its shelf life (Idah, 2013). The most important factor in this case is the prevention of many losses during post-harvest at several stages involved in the fish marketing chain. Post-harvest, handling, processing and transportation of fish require particular care in order to ensure proper quality and safety. Retaining the nutritional value of the fish, preserving the benefits of its rich composition and avoiding costly and debilitating effect of fish-borne diseases are vital (Sulieman, 2012). It was observed that processing and storage significantly affected the proximate composition of red fish. The most important is their general reduction effect on the moisture content which is an index of perishability (Holma and Maalekuu, 2013).

These methods include drying fish by smoking which is referred to as smoke dried, exposing fish to sunlight which is known as sun drying, using preservative additives such as salt, therefore having the salted fish and also canning (Adenike, 2014).Smoking, drying and curing of fish either as a means of prolonging shelf life, or to produce desired flavors and texture has been practiced by many societies for centuries. In tropical countries there are many traditional methods including direct sun drying with the fish placed either directly on the ground or on mats or racks. Some of these processes involve brining or dry salting. The quality of smoked, cured and dried fish can be assessed using a range of physical, chemical and organoleptic methods (Adam and Sidahmed, 2012.The various processing methods applied to fish have different effects on the quality of fish. Recently, a number of researchers had evaluated the spoilage of seafood in general and that of fish in particular (Adenike, 2014) and this also includes the effects of different processing and cooking methods on the nutritional composition of different species of fish. Though the processes are important for preservation, the physical and nutritional quality of fish might be compromised. This is because, it has been observed that different processing and drying methods have different effects on the nutritional compositions of fish (Oparaku and Mgbenka, 2012).

Therefore, the aim of the study was to assess the nutritional value and consumer acceptability of fresh, sundried, and smoke dried Tilapia species in Zambia.

\section{MATERials AND MeTHOdS}

A survey on three major markets in the Copper belt Province namely Chisokone, Roan, and Masala in Kitwe, Luanshya and Ndola respectively was conducted using a combination of structured questionnaire and focus group discussions with fish consumers of different categories and areas. Samples of fresh, smoke dried and sun dried tilapia were collected for nutritional examination which was done at the Copper belt University Environmental Engineering Laboratory. A Proximate chemical analysis was conducted to determine; protein content, fat content, ash content, dry matter and moisture. A total number of 100 questionnaires were administered to fish consumers with 50 questionnaires in Kitwe, 25 questionnaires in Luanshya and 25 questionnaires in Ndola to determine the consumer acceptability.

\subsection{Proximate Chemical Analysis}

Proximate compositions of fish were determined according to the standard methods described by Association of Official Analytical Chemists (AOAC, 1990; 2002; 2005). Fish samples were finely 
ground and chemical analysis for all samples were estimated in triplicate according to the standard methods described by Association of Official Analytical Chemists (AOAC, 2005).

\subsection{Crude Protein (CP)}

Crude protein levels were determined indirectly from the analysis of total nitrogen by the MicroKjeldahl method after acid digestion. The amount of protein in the sample was calculated by multiplying the amount of nitrogen by 6.25 (since protein is $16 \%$ nitrogen, 6.25 times the amount of total nitrogen in the sample would equal the total amount or $100 \%$ of the protein in the sample). $\%$ Crude protein $=$ Amount of protein in sample/wt of sample $\mathrm{x} 100$.

\subsection{Crude Fat (CF)}

Crude fat was determined using the Soxhlet extraction apparatus. The amount of fat was calculated by measuring the difference between the weights of the round bottomed flask with fat extract and the weight of an empty round bottomed flask.

$$
\% \text { of fat }=\frac{[\text { weight of flask }+ \text { extract }]-\text { tare wt of flask }}{\text { weight of sample }} \times 100
$$

\subsection{Ash}

The ash was determined by putting the sample in a muffle furnace at $550^{\circ} \mathrm{C}$ for 5 hours. Then the ash was calculated as a percentage by dividing weight of ash by weight of the sample and percentage of dry matter of the sample multiplied by $100(\% \mathrm{Ash}=\mathrm{Wt}$ of ash/Wt of original sample $\mathrm{x} 100)$.

$$
\% \text { ash }=\frac{[B-A] \times 100}{\text { weight of sample }}
$$

\subsection{Dry Matter}

Dry matter was determined by drying samples in an oven maintained at $105^{\circ} \mathrm{C}$ for 5 hours. The difference between the initial weight of the sample and that after drying was recorded. Dry matter of samples was calculated by weight loss on drying using the formula: \% DM (dry matter) $=\mathrm{Wt}$ of sample after drying/Wt of sample before drying x 100 and \% Water (moisture) $=100-\%$ DM.

$$
\% \text { Dry Matter }=\frac{B}{A} \times 100
$$

Where $\mathrm{A}=$ Weight of sample and moisture dish before drying

$\mathrm{B}=$ Weight of sample and moisture dish after drying

\section{RESULTS AND DISCUSSIONS}

\subsection{Results}

\subsubsection{Protein Content}

Figure 1 shows the amount of crude protein in smoke dried, sun dried and fresh fish samples.

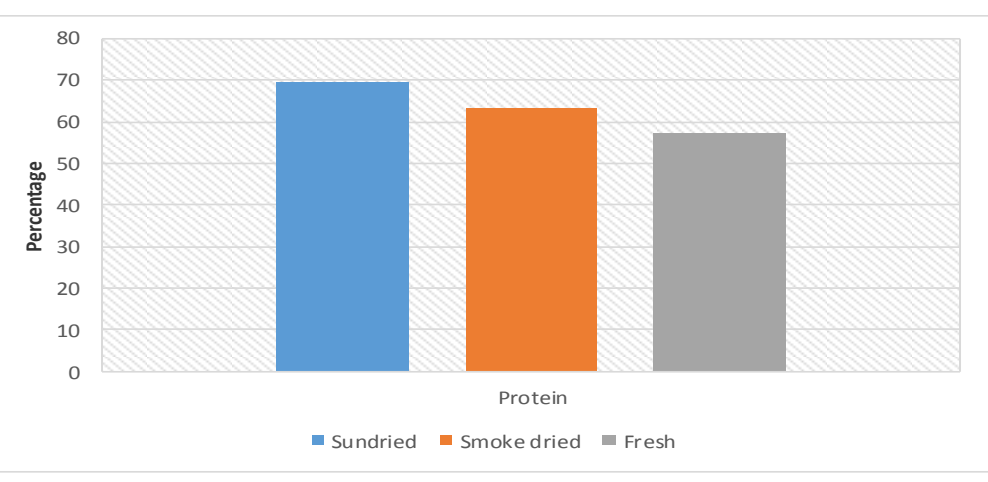

Figure1. Crude protein content of sundried, smoke dried and fresh fish samples.

Figure 1 shows the average means among the sampled fish species namely fresh, sundried, and smoke dried. The average mean for crude protein in sun dried was $69.4 \%$, whereas the smoke dried and fresh was $63.2 \%$ and $57.4 \%$ respectively. 


\subsubsection{Crude Fat}

Figure 2 shows the amount of crude fat in sundried, smoke dried and fresh fish samples.

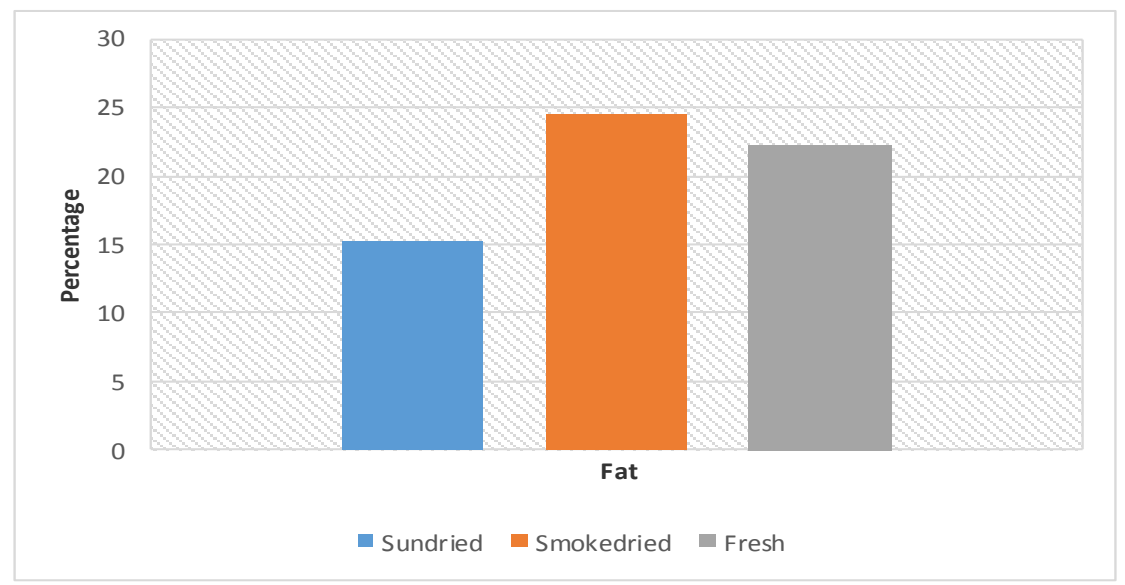

Figure2. Crude Fat content in sundried, smoke dried and fresh fish samples

The average crude fat in sundried, smoke dried and fresh were $15.2 \%, 24.6 \%$ and $22.3 \%$ respectively. This therefore implied that the smoke dried fish sample had the highest content of fat and sundried recorded the least.

\subsubsection{Ash Content}

Figure 3 shows the ash content in sundried, smoke dried and fresh fish samples.

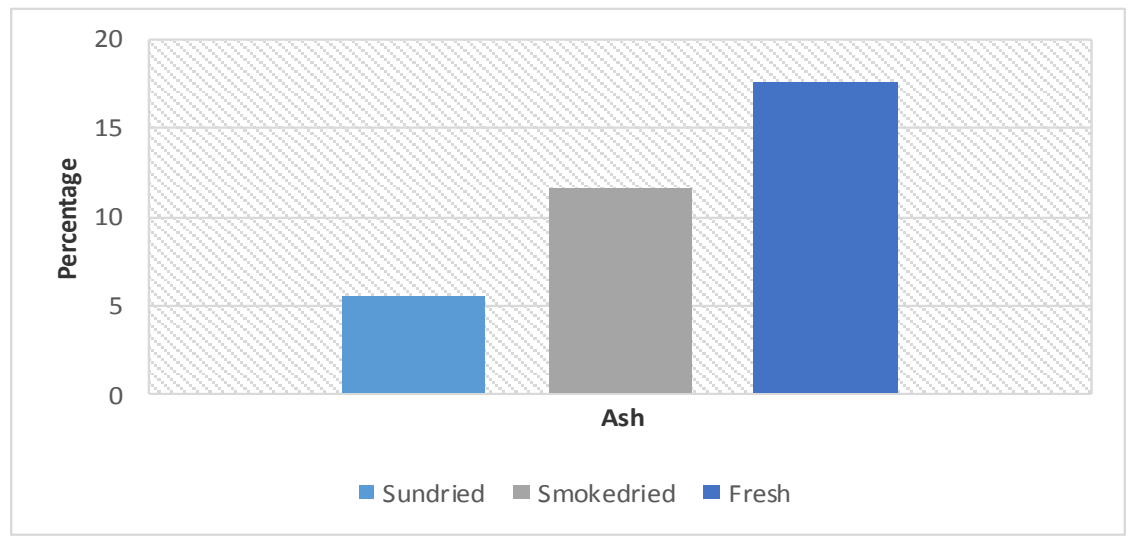

Figure3. Ash content in sundried, smoke dried and fresh fish samples.

Fresh fish samples had the highest level of ash with $17.6 \%$ followed by smoke dried with $11.6 \%$ and sundried had the least ash among the three which was $5.5 \%$.

\subsubsection{Dry Matter}
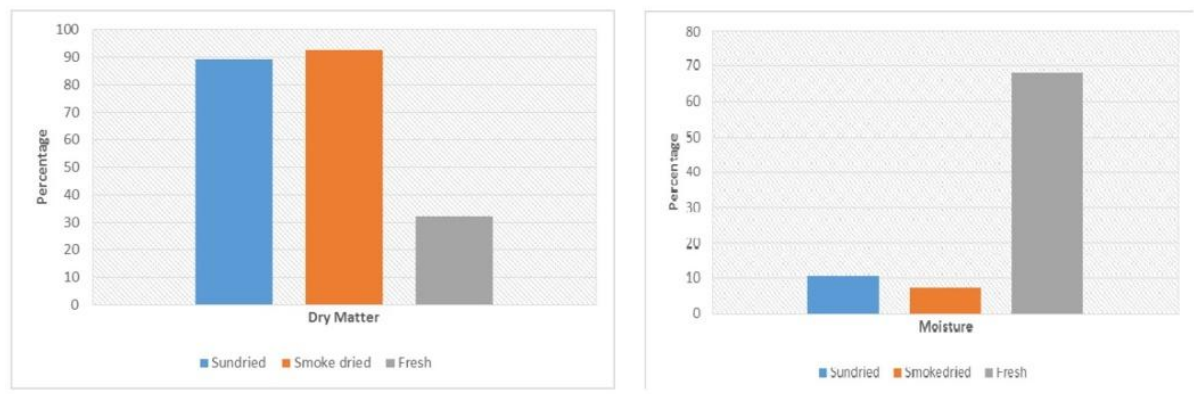

Figure4. Dry Matter and moisture content in sundried, smoke dried fresh fish samples 
The highest level of dry matter was recorded in smoke dried with $92.63 \%$ whereas fresh recorded the least amount of dry matter with $32.1 \%$ and sundried had $89.2 \%$ of dry matter.

\subsubsection{Cheapest Fish on the Market}

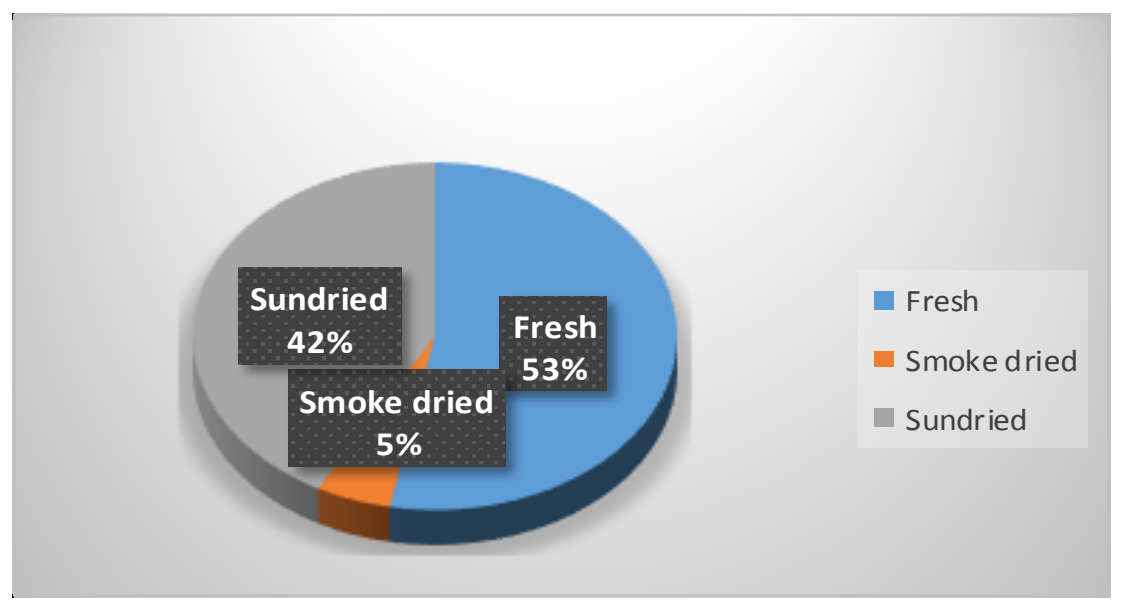

Figure5. Cheapest among sundried, smoke dried and fresh fish

Figure 5 shows the cost of fish on the market based on the survey conducted within the three major markets on the Copper belt Province of Zambia. Fresh fish was ranked the cheapest by most consumers representing $53 \%$ and it was followed by sundried with $42 \%$. Smoke dried happened to be the least cheap fish on the market represented by only $5 \%$.

\subsubsection{Fish Preference}

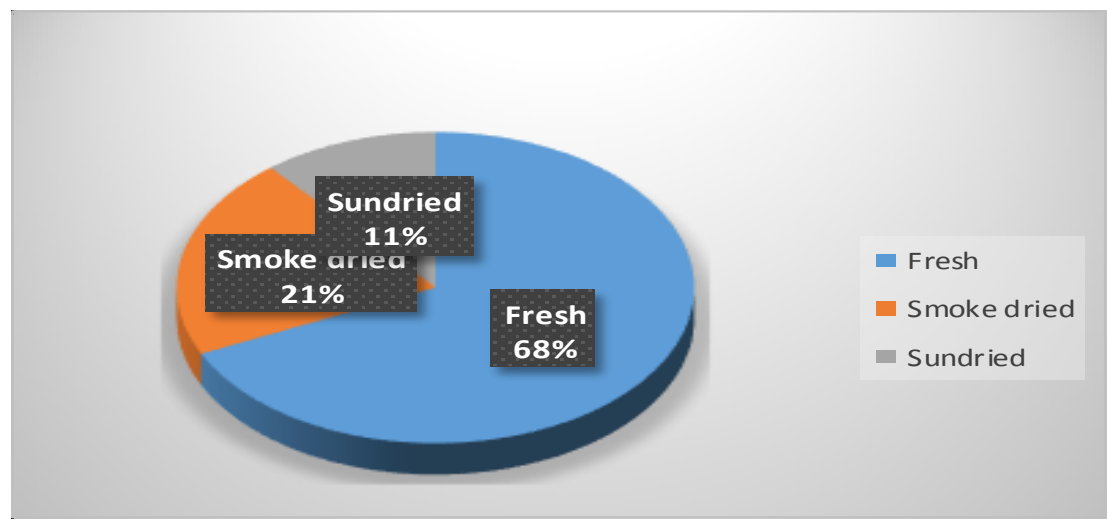

Figure6. Consumer fish preference variations

Figure 6 shows the variation in fish preference among consumers that took part in the survey from the three major markets on the Copperbelt namely Chisokone, Roan and Masala. The most preferable fish was fresh which was ranked at $68 \%$ and followed by smoke dried and sundried ranked at $21 \%$ and $11 \%$ respectively.

\section{DISCUSSION}

\subsection{Proximate Chemical Composition}

Nutritional value of fish may sometimes be altered or rather compromised depending on the way it is brought on the market. In most cases, the available and most common types of Tilapia species on the market are either, fresh, sundried, and smoke dried fish. The nutritive value and how consumers respond differs with each one, and in some cases most fish dealers have ended up having a commodity which is undervalued on the market thereby losing out on profit.

The various forms of fish preservation methods used to extend the shelf life of fish include: salting, roasting, drying and freezing (Mphande and Chama, 2015; Sililo et al., 2016). It has been observed that different processing methods have different effects on the nutritional compositions of fish (Holma and Maalekuu, 2013). According to the authors, some traditional processes in food preservation may 
also destroy or remove some essential nutrients or decrease their digestibility (Holma and Maalekuu, 2013). The bio-chemical composition (proximate composition and $\mathrm{pH}$ value) of fish is an important aspect in fish processing as it influences both the keeping quality and the technological characteristics of the fish (Farzana Binte Farid et al., 2014). Similarly, Mphande and Chama (2015), observed that processing and storage significantly affected the proximate composition of fresh water fish species and their effect varied from species to species.

Protein is the most important nutrient component that fish supplies to the human body. According to Farzana et al. (2014), fish supplies protein of high class quality compared to protein of other animal sources. With reference to Figure 1, the highest amounts of protein composition (69.4\%) was recorded in sundried fish and the least in fresh fish (57.4\%). This therefore concludes that dried fish is the most nutritious type. These results are in agreement with the findings of Khuda (1962) and Farzana et al., (2014) who both reported that dried fish contains more nutrient than fresh fish.Holma and Maalekuu (2013) also reported that smoked fish recorded the highest crude protein content.Farzana et al., (2014) also observed that nutritionally dehydrated products are very good and neither the nutritive value nor the digestibility of the protein is adversely affected due to dehydration process. With smoking, some reports have indicated that protein is increased (Fapohunda and Ogunkoya, 2006) while others have argued that there is a decrease in the nutrient (Arannilewa, 2005). The decrease has been widely attributed to the loss in available lysine which according to Arannilewa (2005) may vary from 6-33\% at $25^{\circ} \mathrm{C}$ to $53-56 \%$ at $40^{\circ} \mathrm{C}$ during hot smoking and an addition from Clifford (1980) shows a $25 \%$ loss of available lysine on the surface and a $12 \%$ loss at the center of hot smoked fish. Furthermore, Akande (1998) made an observation that lysine reduction was directly proportional to the temperature and duration of smoking.

Fat was found to be high in smoke dried samples with composition of about $24.6 \%$ compared to fresh and smoke dried with $22.3 \%$ and $15.2 \%$ respectively. The finding can be attributed to the different behavior of smoke dried tilapia species in terms of fat composition when subjected to different temperature treatments (Idah, 2013) and therefore, the results can be said to be dependent on the smoking temperature associated with the samples. Many other studies have indicated a reduction in fat composition in smoke dried fish especially when smoking is done at high temperatures, according to Ahmed et al., (2011) higher temperatures during smoking contributes to the loss of fat in fish. However, several factors determine the amount of fats in fish species, this includes; diet, temperature, salinity, selective mobilization and distribution.

Ash is a measure of the mineral content in the food item. Ash is the inorganic residue remaining after the water and organic matter have been removed by heating in the presence of oxidizing agents, which provides a measure of the total amount of minerals within a food. Analytical techniques for providing information about the total mineral content are based on the fact that the minerals (the "analyte") can be distinguished from all the other components (the "matrix") within a food in some measurable way (Holma and Maalekuu, 2013. In this study, the fresh samples retained the highest amount of ash compared to the smoke and sun dried. Generally, the amount of ash in the fish is influenced by the size and the bone to flesh ratio, this is why smaller sized fish species tends to have more ash because of the higher bone to flesh ratio (Daramola et al., 2007). Sizes of fish samples in this study were almost the same hence the variations could have resulted from loss of moisture during burning. The results could have also been due to variation in the amount and quality of food that the fish eats from their respective habitats.

The fresh fish sample indicated a high content of moisture as compared to smoked and sun dried tilapia species fish samples, the results can be attributed to the loss of water during the process of either smoking or sun drying (Ande et al., 2012). On the other hand, it is a known fact that most of the fresh fish body is made up of water hence the higher content of moisture in fresh fish sample. Indeed, moisture is vital for ensuring good palatability of fish. However, it must be watched carefully to ensure that it does not increase too much as it can create a conducive environment for microbial growth (Mphande and Chama, 2015). With reference to Figure 4, fish samples of tilapia i.e. sundried and smoke dried indicated less moisture content than that of sundried, however, these findings are in line with that of Ande et al., (2012) who concluded that there is a great loss of water during the smoking process. According to Shehu et al., (2013), during smoking and sun drying processes, approximately one-quarters and one thirds of moisture is lost, which means that both processes are responsible for the lower moisture values indicated in this study. Furthermore, the study shows a huge 
variation in dry matter between dried fish samples and the fresh fish, this generally is the material that remains after the removal of water according to Figure 4.

\subsection{Fish Market And Consumer Acceptance}

\subsubsection{Cheapest Fish on the Market}

Having a profitable and beneficial system is an important part to individuals involved directly or indirectly, therefore the study was important because it aimed at providing such information which would be to the benefit of fish suppliers, the consumers, researchers and other stakeholders. Therefore, keeping the quality of fish and fish products at its best is the most important issue in any kind of fish processing (Farzana, Gulshan, Mosarrat and Begum, 2014).

Fish market participation is generally dependent on four major factors to a great extent, this includes; household size, distance to the nearest marketing channel, price of commodity and sex of fish farmer or marketer (Anthony et al., 2012). Effective consideration of the factors underlying fish market participation was at play in determining how the prices of tilapia species on the market are determined in Ndola, Kitwe and Luanshya towns on the Copperbelt Province of Zambia. Most of the respondents ranked fresh fish as the cheapest when compared to smoke and sundried (Figure 5), hence they bought it in bulky. One of the reasons advanced towards the low price of the fish, was attributed to little effort involved in processing it. The findings were in agreement with Malumbe and Musuka (2013), whose study revealed that about $62.5 \%$ of the consumers purchased more of fresh fish compared to smoke dried and sun dried. Similarly, Anthony et al., (2012) reported that the price of fish can be positively and significantly related to the probability of selling it. However, Mphande and Chama (2015), findings seem to broadly suggest that fish should be consumed fresh or stored for a short time after freezing in order to maximize the nutritional benefits to the consumer.

Malumbe and Musuka (2013), revealed that tilapia was the most popular fish species that was cheap and offered at a very acceptable price, as such there was good market for it in Zambia. In addition, the authors reported that tilapia was readily available in both capture and under fish farming. The fish was hard and did not easily go bad.

\subsubsection{Consumer Preference}

Consumer preference is a factor which is commonly determined and influenced by socio-demographic characteristics such as gender, age, income, level of education, employment status, location and family size (Kevin et al., 2014). In this study, most respondents preferred fresh fish to smoke and sundried. The major aspects for preference included taste and the rate and quantity of buying. Furthermore, it was observed that tilapia was easily prepared in any form. Besides, no religious negativity were attached to its consumption compared to other fish species. Some respondents preferred fresh fish based on cookability, because it was easier to prepare and yet others preferred frying to boiling, roasting and grilling.

Most large families admitted that fresh fish was able to meet their family expectations and satisfaction. These findings were in agreement with Malumbe and Musuka (2013), who reported that the tastiest fish was fresh. This study observed that many respondents were unable to afford either sun dried or smoke dried breams often times because they were perceived to be expensive and failed to meet the needs of most households. Kevin et al., (2014) revealed that individuals could be forced to purchase and consume food items to satisfy the large household especially in cases were income was low. Only individuals in the high or middle income classes and those who based their preference on health reasons were the ones who opted for either sun dried or smoke dried. According to Kevin et al.,(2014), education was assumed to enlighten consumers about the health and other benefits of fish consumption hence, positively influencing the general preference of consumers.

\section{Conclusions}

The nutritional value and consumer acceptance of tilapia species can be viewed as important factors in as far as consumers and suppliers of fish were concerned. According to this study, it can be concluded that there were several factors underlying the acceptance of sundried, smoke dried and fresh tilapia fish species on the market. These factors included; health reasons, preference, taste, diversity of preparation methods and family satisfaction. On the other hand, processing methods were discovered to affect both the nutrient composition and buying of fish by consumers. Many consumers attributed 
their less attention for sundried and smoke dried to higher prices which were attributed to the effort in coming up with the end result of the commodities as compared to fresh fish which is direct from the water to the market.

The study showed that sundried contained high level of proteins, fats were high in smoke dried and fresh showed higher content of ash. Moisture and dry matter were high in fresh and smoke dried respectively. Fresh fish happened to be the most preferred and at the same time appeared to be the most accepted Tilapia fish on the market. The study also revealed that fresh fish was the cheapest compared to both sundried and smoke dried. The findings therefore rejected the null hypothesis which stated that Fresh, Sundried, and Smoked dried tilapia species would give the same results in nutritional value and consumer acceptance. However, it can be concluded that processing methods affects the nutrient quality of fish differently and consumers base their acceptance on factors to do with their satisfaction.

\section{ACKNOWLEDGEMENT}

The authors would like to extend their sincere appreciation to the Copperbelt University for the financial, moral, and material support rendered without which this project wouldn't have come this far. Special gratitude goes to everyone that participated in making this project a success.

\section{REFERENCES}

[1] Adam S. H. M. and Sidahmed M.A., (2012). Effect of Drying System on Chemical and Physical Attributes of Dried Catfish Meat (Clarias Sp.). World's Vet. J. 2(1): 01-04. Journal homepage: http://wvj.scienceline.com/

[2] Adenike, O. M., (2014). The Effect of Different Processing Methods on the Nutritional Quality and Microbiological Status of Cat Fish (Clarias lezera). Food Processing and Technology.

[3] Ahmed A, Dodo A, Bouba A, Clement S, Dzudie T., (2011). Influence of traditional drying and smokedrying on the quality of three fish species (Oreochromis niloticus, Silurusglanis andArius parkii) from Lagdo Lake. Cameroon. J. Anim. Vet. Advan. 10(3):301-306.

[4] Akande, G. R., Oladosu, O. H., and Tobor, J. G., (1998). A Comparative technical and economic appraisal of fish smoking: Two traditional ovens and a new Improved Magbon-Alade oven. FAO Fisheries Report, 574, 70-75.

[5] Ande Sesugh, Leke Luter, Eneji Ishaq and Yakubu Sunday., (2012). Proximate analysis of smoked and unsmoked fish (cat and tilapia) in Ombi River Lafia Nasarawa State Nigeria.Elixir Food Science 53 11801-11803.

[6] Anthony O. Onoja, Usoroh, B. B. Adieme, D. T. Deedam, N.J., (2012). Determinants of Market Participation in Nigerian Small-Scale Fishery Sector: Evidence from Niger Delta Region. The Journal of Sustainable Development. Vol. 9, Iss. 1 (2012), Pp. 69 - 84.

[7] AOAC. (Association of Official Analytical Chemist) 1990. Official methods of Analysis (15 ${ }^{\text {th }}$ ed.). Inc., Suite, 400, Arlington, Virginia. Vol.2: 685-1298 pp.

[8] A.O.A.C. (Assocition of Official Analytical Chemists) (2002). Methods of Analysis. 17th edition. Washington D.C., USA.

[9] AOAC, (Association of Official Analytical Chemists) (2005). Official Methods of Analysis (18 ${ }^{\text {th }}$ ed.). Washington D.C., USA.

[10] Arannilewa, S.T., Salawa, S.O. Sorungbe, A.A. and Olasalawu, B.B., (2005). Effect of frozen period on the chemical, microbiological and sensory quality of frozen tilapia (Sarotherodon galilaleus). African Journal of Biotechnology, 4(8): 852-855

[11] Daramola, J. A, Fasakin, E. A and Adeparusi, E. O., (2007). Changes in physiochemical and sensory characteristics of smoke-dried fish species stored at ambient temperature. African Journal of Food, Agriculture, Nutrition and Development 2007; 7(6): 1-16.

[12] Fapohunda, O. O., and Ogunkoya, M., (2006). Effect of smoke-drying on the proximate composition of Tilapia zillii, Parachanna obscura and Clarias gariepinus obtained from Akure, Ondo-State, Nigeria. Animal Research International, 3(2), 478-480.

[13] Farzana Binte Farid, Gulshan Ara Latifa, Mosarrat Nabila Nahid and Mohajira Begum, (2014).Effects of Salting on the shelf lives extension of sun-dried Shoal (Channa striatus Bloch, 1801) and Taki (C. punctatus; Bloch, 1793) fish-products stored at room temperature $\left(27^{\circ} \mathrm{C}-30^{\circ} \mathrm{C}\right)$.International Journal of Multidisciplinary Research and Development 2014; 1(7): $42-47$.

[14] Holma, K. A., and Maalekuu, B.K., (2013). Effect of traditional fish processing methods on the proximate composition of red fish stored under ambient room conditions. American Journal of Food and Nutrition 
Print: ISSN 2157-0167, Online: ISSN 2157-1317, doi:10.5251/ajfn.2013.3.2.73.82 (C) 2013, ScienceHu $\beta$, http://www.scihub.org/AJFN

[15] Idah, P.A. and Ifannyi, N., (2013). Effects of smoke-drying (Temperatures and time on physical and nutritional quality parameters of Tilapia (Oreochromis niloticus), International Journal of Fisheries and Aquaculture Vol. 5(3), pp. 29-34, March.

[16] Kefi, A. S. and Mukuka R. M., (2015). The Fisheries Sector in Zambia: Status, Management, and Challenges. Indaba Agricultural Policy Research Institute, Technical Paper No. 3. August, 2015

[17] Kevin, O. Obiero, Mary, A. Opiyo, Jonathan, M. Munguti, Paul, S. Orina, Domitila Kyule, Ernest Yongo, Cecilia, M. Githukia, Harrison Charo-Karisa., (2014). Consumer preference and marketing of farmed Nile Tilapia (Oreochromis niloticus) and African Catfish (Clarias gariepinus) in Kenya: Case Study of Kirinyaga and Vihiga Counties. International Journal of Fisheries and Aquatic Studies 2014; 1(5): 67-76

[18] Khuda, M. A. A., (1962). Chemical composition and quality of traditionally processed fish, Pak. J. Sci. Ind. Res., 5(2): 70-73

[19] Malumbe, D. and Musuka, C. G., (2013). The Most Preferred and Tasty Fish in Zambia: A Case Study of Three Copperbelt Province Markets. Pakistan Journal of Nutrition 12 (11): 960-965, 2013. ISSN 16805194 (C) Asian Network for Scientific Information, 2013

[20] Mphande and Chama (2015). Preservation Methods and Storage Period Affect the Mineral and Moisture Composition of Freshwater Fish Species. International Journal of Food Science and Nutrition Engineering 2015, 5(3): 147-153 DOI: 10.5923/j.food.20150503.06.

[21] Musumali, M.M., Heck, S., Husken, S.M.C., Wishart, M., (2009). $\quad$ Fisheries $\quad$ in Zambia: An undervalued contributor to poverty reduction. The World Fish Center/ The World Bank. Policy Brief 1913.

[22] Oparaku, N. F and Mgbenka, B. O., (2012). Effects of electric oven and solar dryer on a proximate and water activity of Clarias gariepinus Fish. European J. Sci. Res. $\quad$ 81(1):139 -144.

[23] SADC (2016). SADC Fisheries Fact Sheet. 1.2.

[24] Shehu, L. Akintola, Ayodele Brown, Abubakar Bakare, Oluwafemi, D. Osowo, Beatrice, $\quad$ O. Bello., (2013). Effects of Hot Smoking and Sun Drying Processes on Nutritional Composition of Giant Tiger Shrimp (Penaeus monodon, Fabricius, 1798). Pol. J. Food Nutr. Sci., 2013, Vol. 63, No. 4, pp. 227237 DOI: 10.2478/v10222-012-0093-1 http://journal.pan.olsztyn.pl

[25] Sililo, S., Musuka, C.G., and Kefi, A.S., (2016). Fish Imports and Their Contribution towards Feeding an Ever-Growing Population in Zambia. Innovative Techniques in Agriculture 1.2 (2017): 107-115.

[26] SNDP (2017). Seventh National Development Plan (SNDP), 2017-2021. Ministry of National Development Planning. Lusaka. Zambia

[27] Sulieman, Adam H. M. and Sidahmed, M. A., (2012). Effect of Drying System on Chemical and Physical Attributes of Dried Catfish Meat (Clarias Sp.). World's Vet. J. 2(1): 01-04.

[28] Zambia Development Agency (ZDA) (2011). Zambia Agriculture Sector Profile. Agriculture, Livestock and Fisheries profile.

Citation: H. K. Kanyemboo and C. G. Musuka, "Nutritional Value and Consumer Acceptability of Fresh, Sundried and Smoke-Dried Tilapia in Zambia", International Journal of Forestry and Horticulture (IJFH), vol. 3, no. 4, p. 6-14, 2017. http:// dx.doi.org/10.20431/2454-9487.0304002

Copyright: (C) 2017 Authors. This is an open-access article distributed under the terms of the Creative Commons Attribution License, which permits unrestricted use, distribution, and reproduction in any medium, provided the original author and source are credited. 